DOI: $10.2478 / \mathrm{v} 10025-010-0005-\mathrm{x}$

\title{
Hydrochemical characteristics of a spring snowmelt flood in the Upper Wieprz River basin (Roztocze region) in year 2006
}

\author{
Stanisław CHMIEL, Ewa MACIEJEWSKA, Zdzisław MICHALCZYK
}

Maria Curie-Skłodowska University, Department of Hydrography, ul. Akademicka 19. 20-033 Lublin, Poland; stanislaw.chmiel@poczta.umcs.lublin.pl

\begin{abstract}
In order to help develop a better understanding of relevant catchment processes, this paper presents the changes in physico-chemical features of the Wieprz River water during the spring snowmelt flood of 2006. The obtained results showed that the groundwater sampled from the springs and the water sampled from the river had a similar and quite stable composition of the basic physicochemical features in the period of solely groundwater feeding (the river is fed only with the water coming from underground sources). The physico-chemical composition of river water during snowmelt depended on the contribution of surface runoff in total outflow and the flood phase. The correlation coefficients between the discharge in the Wieprz River and the concentrations in the studied indices were significantly negative: $\mathrm{pH}, \mathrm{SEC}, \mathrm{HCO}_{3}, \mathrm{Ca}, \mathrm{Mg}, \mathrm{Na}, \mathrm{Sr}, \mathrm{SiO}_{2}, \mathrm{Cl}, \mathrm{SO}_{4}, \mathrm{~F}$. Significantly positive correlations associated with an increase in discharge were observed in the case of: $\mathrm{K}, \mathrm{NO}_{3}$, $\mathrm{NO}_{2}$, total organic carbon, chemical oxygen demand and biochemical oxygen demand. Step and bidirectional responses were noted during the snowmelt flood in the case of the content of $\mathrm{NH}_{4}$ and $\mathrm{PO}_{4}$.
\end{abstract}

Key words: chemical composition, outflow, Roztocze region, spring snowmelt flood

\section{INTRODUCTION}

Water is the most dynamic component of the geographical environment due to its ability to dissolve and transport various substances. The studies done on rivers are the best document of energy and matter transport effects. Recently, one can observe a growing interest in forecasting river water chemistry changes during extreme events such as floods or droughts, which helps to evaluate the potential contamination of water used not only for domestic purposes but also for industry and environmental management (DOJLIDO and WOJCIECHOWSKA, 2000; WALEWSKI, 1997).

The quantity and quality changes which occur in river water and those resulting from the inflow of water from surface runoff are mainly influenced by hydro- 
meteorological conditions, water flow pathways within the basin, and the degree of anthropogenic environmental changes (CHMIEL, 2005; HARNED, 1988; KOSTRZEWSKI et al., 1994; MAZUREK, 1999; Metody..., 1992; WALLING and WEBB, 1986; ŻELAZNY et al., 2005). It has been assumed that in heavily contaminated rivers the concentration due to the factors of anthropogenic origin decreases as the result of dilution caused by water from surface runoff. In rivers with clean water, there an increase in the concentration indices, while in rivers with medium contamination levels - the response to a change in discharge volume is bidirectional.

\section{THE STUDY AREA AND METHODS}

The aim of the present study was to determine the physico-chemical response of the Wieprz River to intensive snowmelt flooding based on an analysis of physico-chemical properties of the water participating in the hydrologic cycle. The study on physico-chemical properties of the Wieprz River during the snowmelt period was carried out at the Guciów profile, to which water flows from a catchment of $300.3 \mathrm{~km}^{2}$ in area (Fig. 1). The catchment is situated in the northern part of the Roztocze Tomaszowskie region and comprises loess and permeable sand sediments of different origin. As a result, the plateau and slope areas are devoid of surface water. The main groundwater reservoir feeding the river is located in fissured carbonate rocks of Upper Cretaceous formed as opokas, gezas, and marls. The groundwater table in the Wieprz River Valley is at 250-260 m a.s.l., whereas on the plateaus - 290-310 $\mathrm{m}$ a.s.l. The Wieprz Valley extend refers to fissures of bedrock and it is the base for drainage for groundwater table of the so called "Roztocze water-bearing horizon".

In the land use structure of the basin, agricultural lands have the largest share - 60\% (arable lands 79\%, meadows and pastures $21 \%$ ), forests cover $34 \%$, while built-up areas cover less than $5 \%$. This area is characterized by low population density, low urbanization, and in agriculture extensive farming is predominant, which is attested by low fertilizer application levels: $\sim 50 \mathrm{~kg} \mathrm{~N} \cdot \mathrm{ha}^{-1} \cdot \mathrm{year}^{-1}$ and $\sim 20$ $\mathrm{kg} \mathrm{P} \cdot \mathrm{ha}^{-1} \cdot$ year $^{-1}$.

In the period of 1995-2006, the average discharge of the Wieprz River in Guciów amounted to $1.30 \mathrm{~m}^{3} \cdot \mathrm{s}^{-1}$, corresponding to specific runoff of $4.3 \mathrm{dm}^{3} \cdot \mathrm{s}^{-1} \cdot \mathrm{km}^{-2}$ and the runoff index of $136.2 \mathrm{~mm}$ (STĘPNIEWSKA, 2007). In the total outflow, groundwater feeding accounts for over $80 \%$, where the share of direct riverbed drainage and spring feeding is about $50 \%$ of value each (MICHALCZYK, 2004). Seasonally, the highest discharges of the Wieprz River occur in March and April (up to $\left.2 \mathrm{~m}^{3} \cdot \mathrm{s}^{-1}\right)$, whereas the lowest in December $\left(\sim 1 \mathrm{~m}^{3} \cdot \mathrm{s}^{-1}\right)$. Surface runoff reaches the riverbed more often after snowmelt than after rainfall. In the years 1995-2006, ten over-bank floods caused by snowmelt and three over-bank floods caused by rainfall occurred on the Wieprz River in Guciów (SADOWSKA, 2007). 


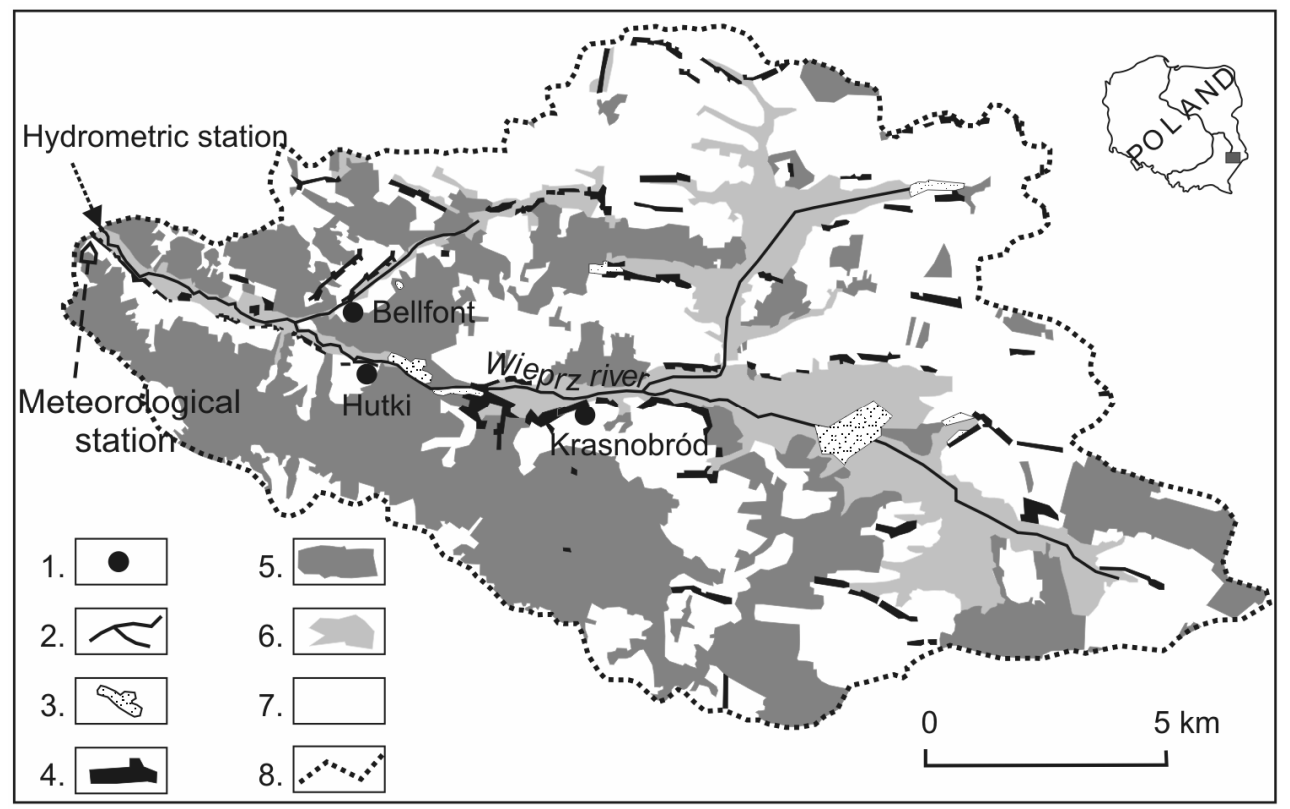

Fig. 1. Location of the Wieprz River catchment; 1 - springs, 2 - rivers, 3 - waters, 4 - built-up areas, 5 - forests, 6 - meadows and pastures, 7 - arable lands, 8 - water divide of the catchment

The maximum flow in this period occurred in March 2005 during spring snowmelt and it was $13.1 \mathrm{~m}^{3} \cdot \mathrm{s}^{-1}$.

The aim of the 2006 study was to capture the physico-chemical response of the Wieprz River in Guciów to intensive snowmelt feeding based on an analysis of physico-chemical properties of the following: rainfall water, surface runoff water, groundwater and river water. Water samples for physico-chemical analyses were taken from the Wieprz River channel every day in the morning. Temperature, water $\mathrm{pH}$, and specific electrical conductivity (SEC) were measured during field investigations. Moreover, in the laboratory of the Roztocze Research Station in Guciów total suspended solids (TSS) were determined gravimetrically and water alkalinity (Alkal.) was determined by titration, based on which the bicarbonate concentration was calculated. The other indices were analysed in the laboratory of the Department of Hydrography, Maria Curie-Skłodowska University in Lublin, using a Pastel UV spectrophotometer by Secoman in order to determine total organic carbon (TOC), biochemical and chemical oxygen demand $\left(\mathrm{BOD}_{5}\right.$ and $\left.\mathrm{COD}_{\mathrm{Cr}}\right)$; a Hach $\mathrm{DR}$ 2000 spectrophotometer to determine $\mathrm{SiO}_{2}$ and $\mathrm{PO}_{4}$, a MIC 3 ion chromatographer by Metrohm to determine: $\mathrm{Ca}, \mathrm{Mg}, \mathrm{Na}, \mathrm{K}, \mathrm{NH}_{4}, \mathrm{Sr}, \mathrm{F}, \mathrm{Cl}, \mathrm{SO}_{4}, \mathrm{NO}_{2}, \mathrm{NO}_{3}$.

To identify the factors which drive the hydrochemical changes in the river, the precipitation water collected daily in the Guciów Research Station, the water flow- 
ing down from the slopes during snowmelt as well as groundwater from the springs in Krasnobród and in Hutki and from the Belfont spring were analysed.

\section{HYDROMETEOROLOGICAL CONDITIONS OF FLOOD}

The flood in the Upper Wieprz River began on $27^{\text {th }}$ March 2006 as a result of the melting of accumulated snow. The analyses of the data from the weather stations located in the Wieprz basin show that nearly $100 \mathrm{~mm}$ of water was accumulated in the snow cover. Intensive snowmelt events were caused by rainfall and an air temperature increase as a result of the inflow of a warm and moist front from the western sector of Europe. Rainfalls which occurred on five successive days in a row $\left(26^{\text {th }}\right.$ March $-3.7 \mathrm{~mm}, 27^{\text {th }}$ March $-1.6 \mathrm{~mm}, 28^{\text {th }}$ March $-17.1 \mathrm{~mm}, 29^{\text {th }}$ March $-4.0 \mathrm{~mm}, 31^{\mathrm{st}}$ March $-3.6 \mathrm{~mm}$ ) melted the snow cover. During the few first days of the flood, the water maintained on the frozen ground, therefore it was possible to observe surface runoff. At the beginning of April - when the ground unfroze, the water began to soak in and consequently the level of flood water on arable lands started to decrease.

During the flood which lasted about two weeks, the discharges in the Wieprz River increased from $0.73 \mathrm{~m}^{3} \cdot \mathrm{s}^{-1}$ to $8.70 \mathrm{~m}^{3} \cdot \mathrm{s}^{-1}$ at the maximum flood wave, but at the end of the flood the discharges decreased to approx. $1 \mathrm{~m}^{3} \cdot \mathrm{s}^{-1}$ (Fig. 2).

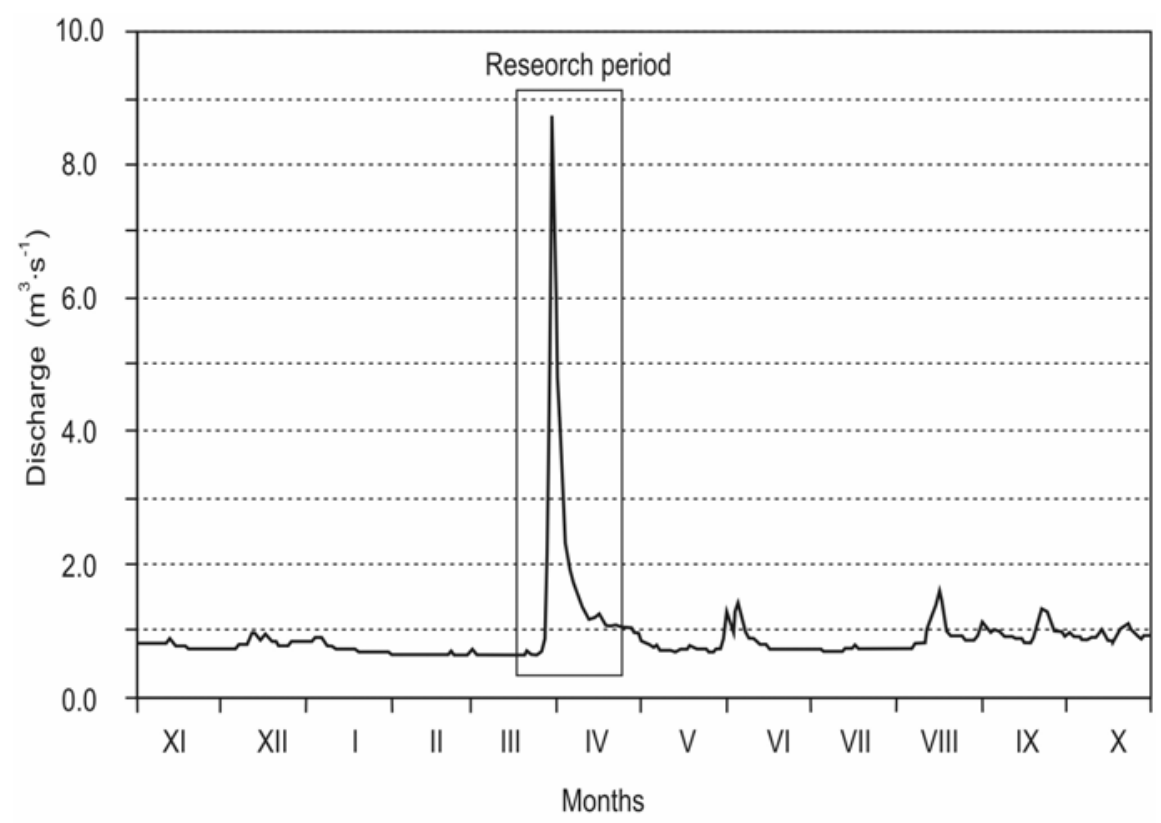

Fig. 2. Daily flows of the Wieprz River in Guciów in 2006 with the designated period of hydrochemical investigations included in the analysis of the snowmelt flood 


\section{RESULTS AND DISCUSSION}

When the Wieprz River was only fed by groundwater, the composition of the water collected from the springs and from the river was similar in terms of basic physico-chemical indices and considerable stability. A great variability in the physico-chemical properties of the Wieprz River water was observed during the snowmelt flood (Tab. 1, Fig. 3); the changes were much smaller for groundwater analysed in the observed springs. That is a typical hydrochemical feature of water from the potamic zone in the plateau area of the Lublin region (CHMIEL, 2005; JANIEC, 1997; Przyrodnicze..., 2004; ŚwIECA, 1998). The physico-chemical composition

Table 1. Characteristic values of the physico-chemical indices of the Wieprz River water at the Guciów profile in Roztocze during the snowmelt flood (based on the determinations from 34 samples from the period $17^{\text {th }}$ March $-20^{\text {th }}$ April 2006) in relation to the physico-chemical properties of the Wieprz River water during solely groundwater feeding and averaged values from 3 springs (Krasnobród, Hutki, Belfont)

\begin{tabular}{|c|c|c|c|c|c|c|c|c|c|c|c|}
\hline \multirow[b]{3}{*}{ Index } & \multirow[b]{3}{*}{ Units } & \multicolumn{10}{|c|}{ Points of water samples taking } \\
\hline & & \multirow[b]{2}{*}{ springs } & \multirow[b]{2}{*}{$\begin{array}{l}\text { Wieprz } \\
\text { River - } \\
\text { dominant } \\
\text { grundwater } \\
\text { feeding }\end{array}$} & \multicolumn{8}{|c|}{ Wieprz River $\left(17^{\text {th }}\right.$ March $-20^{\text {th }}$ April 2006) } \\
\hline & & & & $\begin{array}{l}\text { चี } \\
\stackrel{\Xi}{\Xi}\end{array}$ & 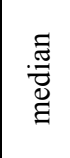 & 声 & 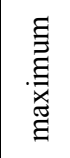 & 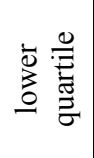 & 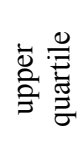 & 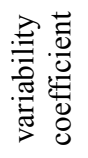 & 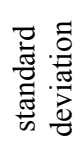 \\
\hline $\mathrm{pH}$ & - & 7.24 & 7.86 & 7.59 & 7.63 & 6.93 & 7.93 & 7.42 & 7.83 & 0.04 & 0.28 \\
\hline TSS & $\mathrm{mg} \cdot \mathrm{dm}^{-3}$ & $<1$ & 9.5 & 24.4 & 13.1 & 5 & 170 & 11 & 19.8 & 1.54 & 37 \\
\hline Alkal. & $\mathrm{mval} \cdot \mathrm{dm}^{-3}$ & 4.09 & 4.17 & 3.26 & 3.61 & 0.70 & 4.21 & 2.98 & 4.10 & 0.31 & 1.01 \\
\hline $\mathrm{HCO}_{3}^{-}$ & $\mathrm{mg} \cdot \mathrm{dm}^{-3}$ & 249 & 254 & 199 & 220 & 43 & 257 & 182 & 250 & 0.31 & 62 \\
\hline $\mathrm{Cl}^{-}$ & $\mathrm{mg} \cdot \mathrm{dm}^{-3}$ & 7.0 & 6.7 & 6.5 & 6.7 & 3.6 & 7.6 & 6.4 & 7.2 & 0.15 & 0.97 \\
\hline $\mathrm{NO}_{3}^{-}$ & $\mathrm{mg} \cdot \mathrm{dm}^{-3}$ & 8.3 & 4.1 & 5.3 & 4.7 & 3.4 & 10.0 & 4.0 & 6.2 & 0.34 & 1.8 \\
\hline $\mathrm{NO}_{2}^{-}$ & $\mathrm{mg} \cdot \mathrm{dm}^{-3}$ & 0.01 & 0.09 & 0.10 & 0.09 & 0.02 & 0.19 & 0.07 & 0.13 & 0.41 & 0.04 \\
\hline $\mathrm{SO}_{4}^{-2}$ & $\mathrm{mg} \cdot \mathrm{dm}^{-3}$ & 21.0 & 18.7 & 17.8 & 18.7 & 9.1 & 20.1 & 18 & 19.4 & 0.16 & 2.93 \\
\hline $\mathrm{PO}_{4}^{-3}$ & $\mathrm{mg} \cdot \mathrm{dm}^{-3}$ & 0.31 & 0.32 & 0.38 & 0.37 & 0.22 & 0.58 & 0.34 & 0.42 & 0.35 & 0.06 \\
\hline $\mathrm{F}^{-}$ & $\mathrm{mg} \cdot \mathrm{dm}^{-3}$ & 0.15 & 0.13 & 0.13 & 0.13 & 0.09 & 0.15 & 0.13 & 0.14 & 0.08 & 0.01 \\
\hline $\mathrm{Ca}^{+2}$ & $\mathrm{mg} \cdot \mathrm{dm}^{-3}$ & 84.3 & 78.0 & 62.3 & 72.9 & 14.6 & 81.8 & 53.0 & 76.6 & 0.32 & 19.6 \\
\hline $\mathrm{Mg}^{+2}$ & $\mathrm{mg} \cdot \mathrm{dm}^{-3}$ & 4.6 & 5.5 & 4.7 & 5.3 & 1.7 & 5.8 & 4.3 & 5.6 & 0.26 & 1.2 \\
\hline $\mathrm{Na}^{+}$ & $\mathrm{mg} \cdot \mathrm{dm}^{-3}$ & 2.0 & 4.6 & 4.2 & 4.5 & 1.7 & 6.8 & 3.6 & 4.9 & 0.24 & 1.0 \\
\hline $\mathrm{K}^{+}$ & $\mathrm{mg} \cdot \mathrm{dm}^{-3}$ & 1.1 & 1.9 & 2.4 & 2.3 & 1.8 & 4.0 & 2.0 & 2.5 & 0.25 & 0.6 \\
\hline $\mathrm{NH}_{4}^{+}$ & $\mathrm{mg} \cdot \mathrm{dm}^{-3}$ & 0.02 & 0.42 & 0.33 & 0.37 & 0.02 & 1.11 & 0.09 & 0.49 & 0.76 & 0.25 \\
\hline $\mathrm{Sr}^{+2}$ & $\mathrm{mg} \cdot \mathrm{dm}^{-3}$ & 0.32 & 0.54 & 0.39 & 0.41 & 0.05 & 0.62 & 0.38 & 0.51 & 0.41 & 0.16 \\
\hline $\mathrm{SiO}_{2}$ & $\mathrm{mg} \cdot \mathrm{dm}^{-3}$ & 24.0 & 24.4 & 16.4 & 16.8 & 3.5 & 24.7 & 13.3 & 23.9 & 0.4 & 6.6 \\
\hline $\mathrm{COD}_{\mathrm{Cr}}$ & $\mathrm{mg} \mathrm{O}_{2} \cdot \mathrm{dm}^{-3}$ & $<2.0$ & 11.8 & 23.2 & 24.7 & 11.2 & 38.5 & 12.7 & 29.2 & 0.38 & 8.8 \\
\hline $\mathrm{BOD}_{5}$ & $\mathrm{mg} \mathrm{O}_{2} \cdot \mathrm{dm}^{-3}$ & $<1.0$ & 5.7 & 11.2 & 12.3 & 5.3 & 18.0 & 6.2 & 13.8 & 0.37 & 4.1 \\
\hline TOC & $\mathrm{mg} \cdot \mathrm{dm}^{-3}$ & $<1.0$ & 3.9 & 7.6 & 8.6 & 3.7 & 12.0 & 4.2 & 9.3 & 0.36 & 2.7 \\
\hline
\end{tabular}




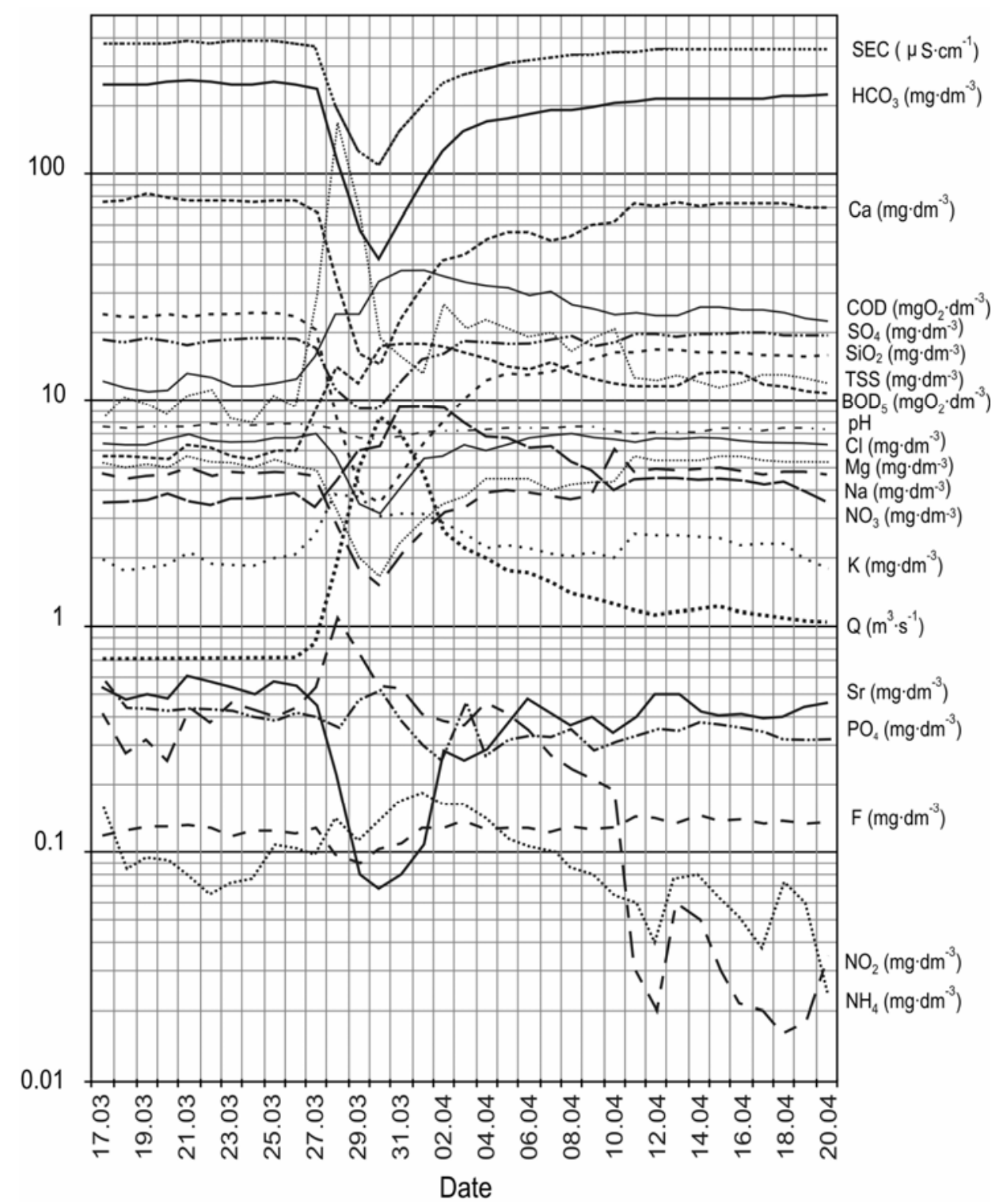

Fig. 3. Changes in physico-chemical features of the Wieprz River water in Guciów during the snowmelt flood (2006)

of the water in the Wieprz River during snowmelt was essentially influenced by the snow cover which contained cumulated pollution and by the transformations which occurred after the contact of snowmelt water with bedrock (CHMIEL, 2005; ECKSTEIN, 1990; JANIEC, 1991; 1997; MAZUREK, 1999; OSMULSKA-MRÓZ and 
SADOWSKI, 1991). Soil thermal conditions determined water infiltration into the bedrock and the level of suspended solids in surface runoff water on the slopes.

The physico-chemical composition of the water in the river during the flood was the result of the contribution of surface runoff to the total outflow and the flood phase. The water which flows down to the river contains less dissolved minerals of natural origin (especially carbonates) than the river water originating from groundwater feeding, but many more substances of anthropogenic character mainly trophic. It documents well the physico-chemical composition of surface runoff water from the slopes into the Wieprz River (Fig. 4). The mixing of those different types of water in the river channel determined the hydrochemical pattern of the flood.

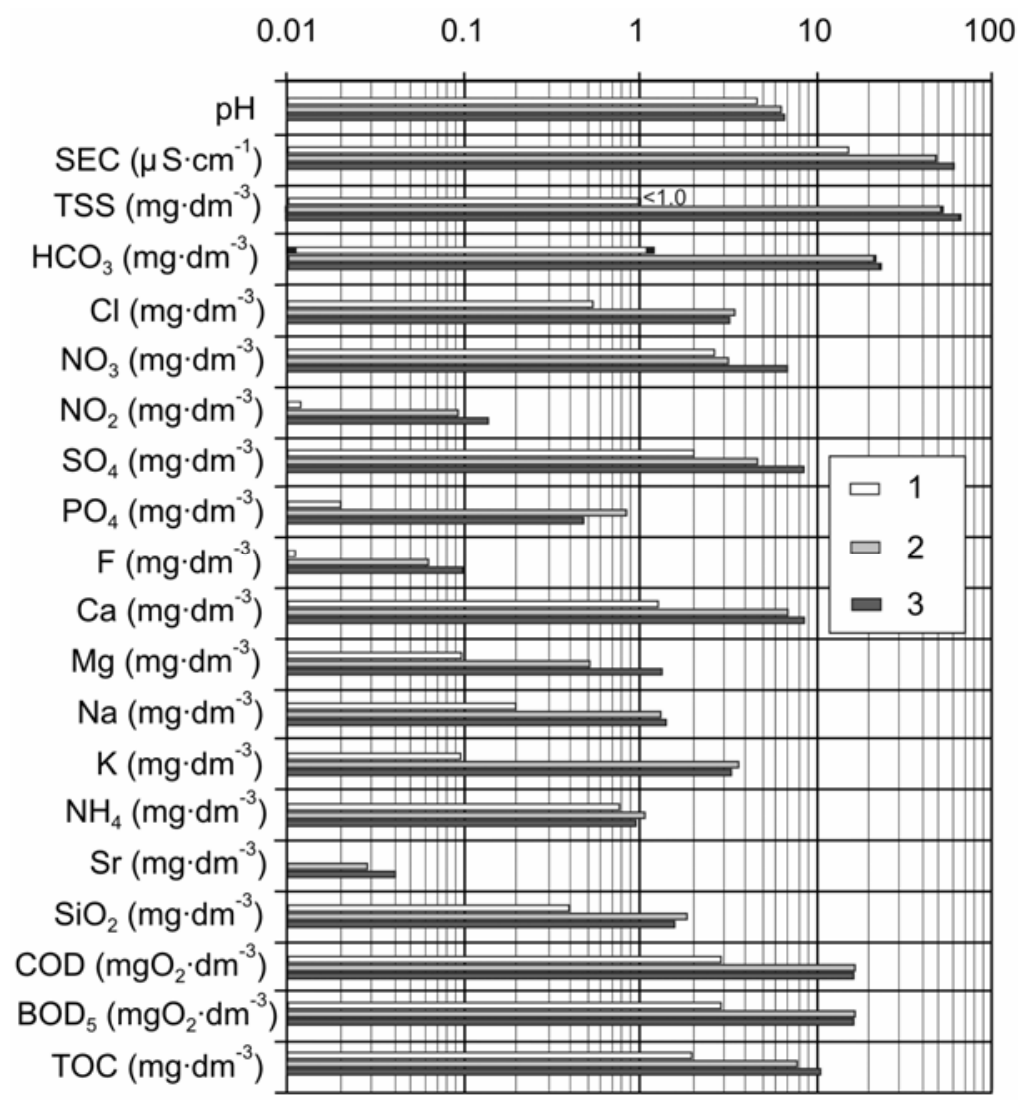

Fig. 4. Physico-chemical composition of precipitation and surface runoff water; 1 -average weighed composition of precipitation water retained in snow cover, 2 - average physico-chemical composition

from 11 water samples taken from slope runoff on $29^{\text {th }}$ March 2008, 3 - physico-chemical composition of surface runoff water from $30^{\text {th }}$ March 2008, calculated on the basis of the discharge and concentration index in the Wieprz River in the period before the flood as well as the discharge and concentration index during the flood - the so-called mixing rule 
The correlation coefficients between the discharge in the Wieprz River and the concentrations in the studied indices were negative: $\mathrm{pH}-0.78$, SEC -0.92 , TH 0.92 , alkalinity $-0.93, \mathrm{Ca}-0.89, \mathrm{Mg}-0.88, \mathrm{Na}-0.81, \mathrm{Sr}-0.87, \mathrm{SiO}_{2}-0.81, \mathrm{Cl}-$ $0.87, \mathrm{SO}_{4}-0.83, \mathrm{~F}-0.59$. During the flood peak phase, there was a decrease in the indices as an effect of dissolved natural minerals (mainly carbonates) and their increase in the flood receding phase. Based on these indices, it is possible to forecast changes during a snowmelt flood. The best match of the correlation between discharge and physico-chemical features was achieved using logarithmic or power functions (Fig. 5).
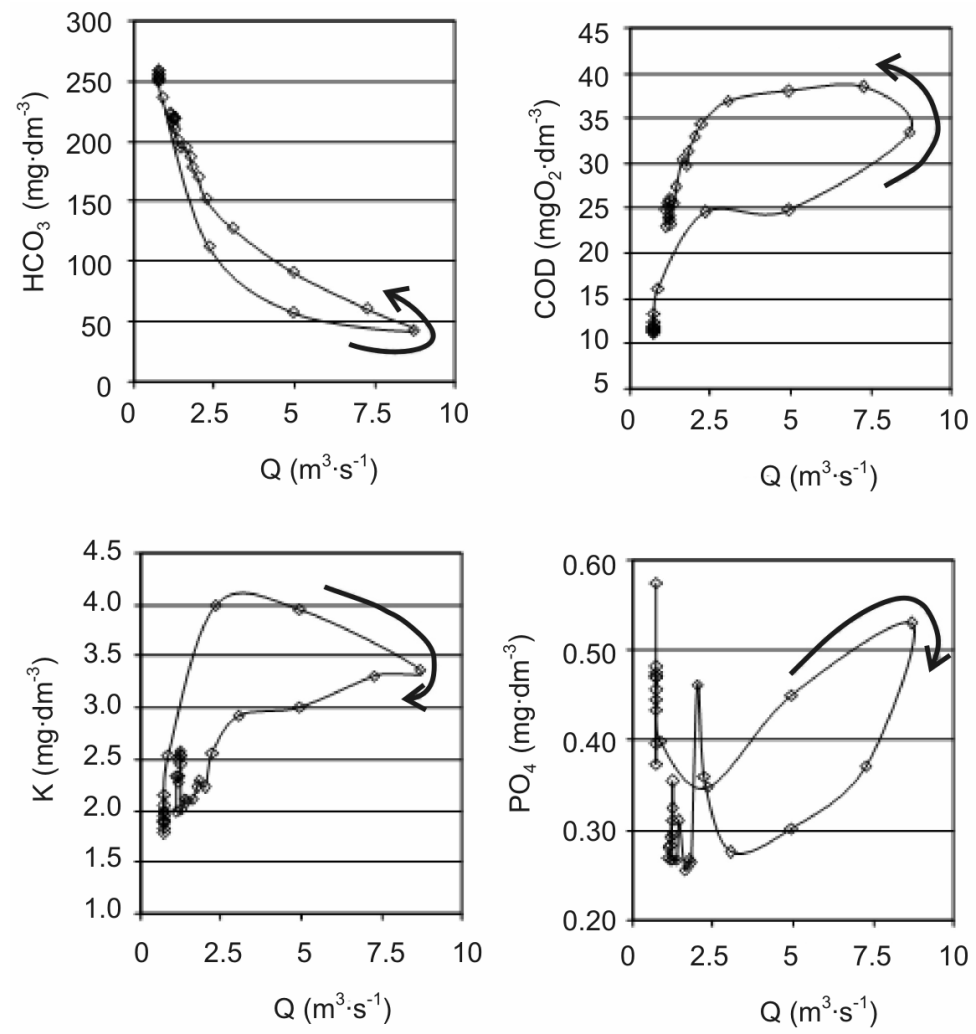

Fig. 5. Relations between the river flow and the studied physico-chemical indices (hysteresis loop) of the Wieprz River water at the Guciów profile

Significantly positive correlations were associated with an increase in discharge observed in the case of: $\mathrm{K} 0.73, \mathrm{NO}_{3} 0.71, \mathrm{NO}_{2} 0.58$, TOC 0.62 , COD 0.63 and BOD 0.62. Step and bidirectional responses were noted during the snowmelt flood in the case the content of: $\mathrm{NH}_{4} 0.34$ and $\mathrm{PO}_{4}$ 0.13. In the group of the coefficients whose values increase during flood or whose response is described by the 
hysteresis effect, it should be supposed that the anthropogenic factor (both in time and space) played a significant role in determining their values. The possibility to forecast the values of these coefficients, on the basis of the known proportion of surface runoff in total runoff, ares then limited.

\section{CONCLUSIONS}

The studies conducted on the Wieprz River show that groundwater taken from the springs and from the river, in the period of solely underground feeding, had a similar and quite stable composition in terms of basic physico-chemical indices. The water flowing down from the slopes had considerably less dissolved bicarbonates and usually more substances of trophic character. The physico-chemical composition of the water in the river during the flood depended on the contribution of surface runoff in total outflow and on the flood phase. Contrary to the flood rising phase, the indices were decreasing as the result of dissolved natural minerals (mainly carbonates). These indices can be used for the genetic division of the water flowing in the riverbed. In the case of the indices whose values increase during flood or whose response is described by the hysteresis effect, it is supposed that the anthropogenic factor (both in time and space) plays a significant role in determining their values. The use of these indices for evaluation of the genetic division of the water flowing in the riverbed is limited. The hydrochemical response of the Wieprz River to intensive snowmelt feeding depended on soil thermal conditions which played an essential role in the ion composition of runoff water.

\section{REFERENCES}

1. Chmiel S., 2005. Rola zasilania podziemnego i spływu powierzchniowego w kształtowaniu cech fizykochemicznych wód rzecznych Wyżyny Lubelskiej i Roztocza. W: Badania hydrograficzne w poznawaniu środowiska. T. 7. (The role of groundwater supply and surface runoff in the development of physico-chemical features of river waters in the Lublin Upland and Roztocze). Lublin, Wydaw. UMCS: 82.

2. Dojlido J., Wojciechowska J., 2000. Metody oceny i klasyfikacji wód. W: Jakość wód powierzchniowych. (Methods for evaluation and classification of waters. In: Quality of surface waters). 10. Ogólnopol. Szkoła Nauk. Gosp. Wod. Warszawa, IMGW: 13-36.

3. ECKSTEIN Y., 1990. Symulacje komputerowe procesów neutralizacji kwaśnych opadów atmosferycznych w glebach i osadach polodowcowych północnego Ohio (St. Zj.). (Modeling the neutralizing processes of acid precipitation in soils and glacial sediments of northern Ohio). Prz. Geol., 11: 510-514.

4. HARNED D.A., 1988. Effects of highway runoff on streamflow and water quality in the Sevenmile Crek basin, a rural area in the Piedmont province of North Carolina, July 1981 to July 1982. U.S. Geol. Survey Water-Supply Pap., 2329: 33.

5. JANIEC B., 1991. Wpływ kwaśnych opadów na odwapnienie rolniczych obszarów Roztocza Zachodniego. W: Chemizm opadów atmosferycznych, wód powierzchniowych i podziemnych. (The effect of acid precipitation on decalcification of agricultural areas of Western Roztocze). 4. Konf. Nauk., Łódź, Wydaw. UŁ: 37-38. 
6. JANIEC B., 1997. Transformacje i translokacje jonowe w wodach naturalnych Roztocza Zachodniego. (Ionic transformations and translocations in natural water of Western Roztocze). Rozpr. habil. Lublin, Wydaw. UMCS: 214.

7. KostrZewSKi A., MAZureK M., ZwolińSKi Z., 1994. Dynamika transportu fluwialnego górnej Parsęty jako odbicie funkcjonowania systemu zlewni. (The dynamics of fluvial transport of the Upper Parsęta River as a reflection of the functioning of the catchments system). Poznań, SGP: 165.

8. MAZuREK M., 1999. Dynamika transportu substancji rozpuszczonych w zlewni młodoglacjalnej (zlewnia Kłudy, Pomorze Zachodnie). (The dynamics of dissolved material transport in a postglacial catchment (Kłuda River catchment, West Pomerania)). Prz. Geogr., 71, 3. Warszawa, Wydaw. Nauk. PWN: 247-267.

9. Metody hydrochemiczne w geomorfologii dynamicznej, 1992. (Hydrochemical methods in dynamic geomorphology). Eds. A. Kostrzewski, M. Pulina. Pr. Nauk. UŚ, 1254: 171.

10. MichalCZYK Z., 2004. Charakterystyka stosunków wodnych. W: Przyrodnicze uwarunkowania dynamiki obiegu wody i natężenia transportu fluwialnego w zlewni górnego Wieprza. (Characteristics of water relations). Ed. A. Świeca. Lublin, Wydaw. UMCS: 50-64.

11. OSMULSKA-MrÓz B., SADKOWSKI K., 1991. Zanieczyszczenie spływów opadowych z dróg szybkiego ruchu w Polsce. (Stormwater runoff pollution from highways in Poland). Ochr. Środ., 2: 73-84.

12. Przyrodnicze uwarunkowania dynamiki obiegu wody i natężenia transportu fluwialnego $\mathrm{w}$ zlewni górnego Wieprza, 2004. (Natural conditions of the water cycle dynamics and fluvial transport rate in the upper Wieprz River catchment). Ed. A. Świeca. Lublin, Wydaw. UMCS: 232.

13. STĘPNIEWSKA S., 2007. Zmienność odpływu górnego Wieprza. W: Obieg wody w środowisku naturalnym i przekształconym. Badania hydrograficzne w poznawaniu środowiska. T. 8. (Runoff variability of the upper Wieprz river). Ed. Z. Michalczyk. Lublin, Wydaw. UMCS: 513-520.

14. ŚwIECA A., 1998. Wpływ czynników antropogenicznych na rzeczny odpływ roztworów i zawiesin na międzyrzeczu Wisły i Bugu. (Antropogenic effects on river discharge of solutes and suspended sediment in the Vistula and Bug interfluve). Rozpr. habil. Lublin, Wydaw. UMCS: 326.

15. WALEWSKi A., 1997. Ocena skażeń środowiska spowodowanych przez powódź. W: Forum naukowo-techniczne - powódź 1997. (Evaluation of flood-related environmental contamination), Warszawa, IMGW: 47-82.

16. Walling D. E., WebB B.W., 1986. Solutes in river systems. In: Solute processes. Ed. S.T. Trudgill. Chichester, John Wiley \& Sons: 253-274.

17. ŻelaZny M., CheŁmicki W., JaszczyńSKa B., Michno A., PietrZak M., RacZaK J., Święchowicz J., 2005. Dynamika związków biogennych w wodach opadowych, powierzchniowych podziemnych w zlewniach o różnym użytkowaniu na Pogórzu Wiśnickim. (The dynamics of biogenic compounds in precipitation water, surface water and groundwater in catchments with different land uses in the Wiśnickie Foothills, southern Poland). Kraków, Inst. Geogr. i Gosp. Przestrz. UJ: 216.

\title{
STRESZCZENIE
}

\section{Hydrochemiczna charakterystyka wiosennego wezbrania roztopowego w zlewni górnego Wieprza w 2006 r. (Roztocze)}

\author{
Słowa kluczowe: odpływ, Roztocze, skład fizyczno-chemiczny, wiosenne wezbranie \\ roztopowe
}

W pracy przedstawiono zmiany cech fizyczno-chemicznych wody rzeki Wieprz w Guciowie (SE Polska) w czasie wiosennego wezbrania roztopowego 2006 roku. Wyniki badań wykazały, że wody gruntowe pobrane ze źródeł oraz 
wody pobrane z koryta rzeki Wieprz w okresie wyłącznego zasilania podziemnego, miały zbliżony i stabilny skład podstawowych wskaźników fizyczno-chemicznych. Podczas roztopów wartości parametrów fizyczno-chemicznych wody w rzece były uzależnione od stopnia przemarznięcia pokrywy glebowej, udziału spływu powierzchniowego w odpływie całkowitym oraz fazy wezbrania. Współczynniki korelacji między przepływem wody w rzece Wieprz a stężeniem badanego wskaźnika były istotne ujemne w przypadku: $\mathrm{pH}-0,78$, SEC $-0,92, \mathrm{TH}-0,92, \mathrm{HCO}_{3}-0,93$, $\mathrm{Ca}-0,89, \mathrm{Mg}-0,88, \mathrm{Na}-0,81, \mathrm{Sr}-0,87, \mathrm{SiO}_{2}-0,81, \mathrm{Cl}-0,87, \mathrm{SO}_{4}-0,83, \mathrm{~F}-0,59$. Istotnie dodatnie zależności związane ze zwiększeniem przepływu zanotowano w przypadku: $\mathrm{K} 0,73, \mathrm{NO}_{3} 0,71, \mathrm{NO}_{2} 0,58$, TOC 0,62 , COD 0,63 i BOD 0,62 . Skokową i różnokierunkową reakcję podczas wezbrania roztopowego notowano w przypadku: $\mathrm{NH}_{4} 0,34$ i $\mathrm{PO}_{4} 0,13$.

Reviewers:

Prof. Edmund Kaca

Prof. Stefan Pietrzak 